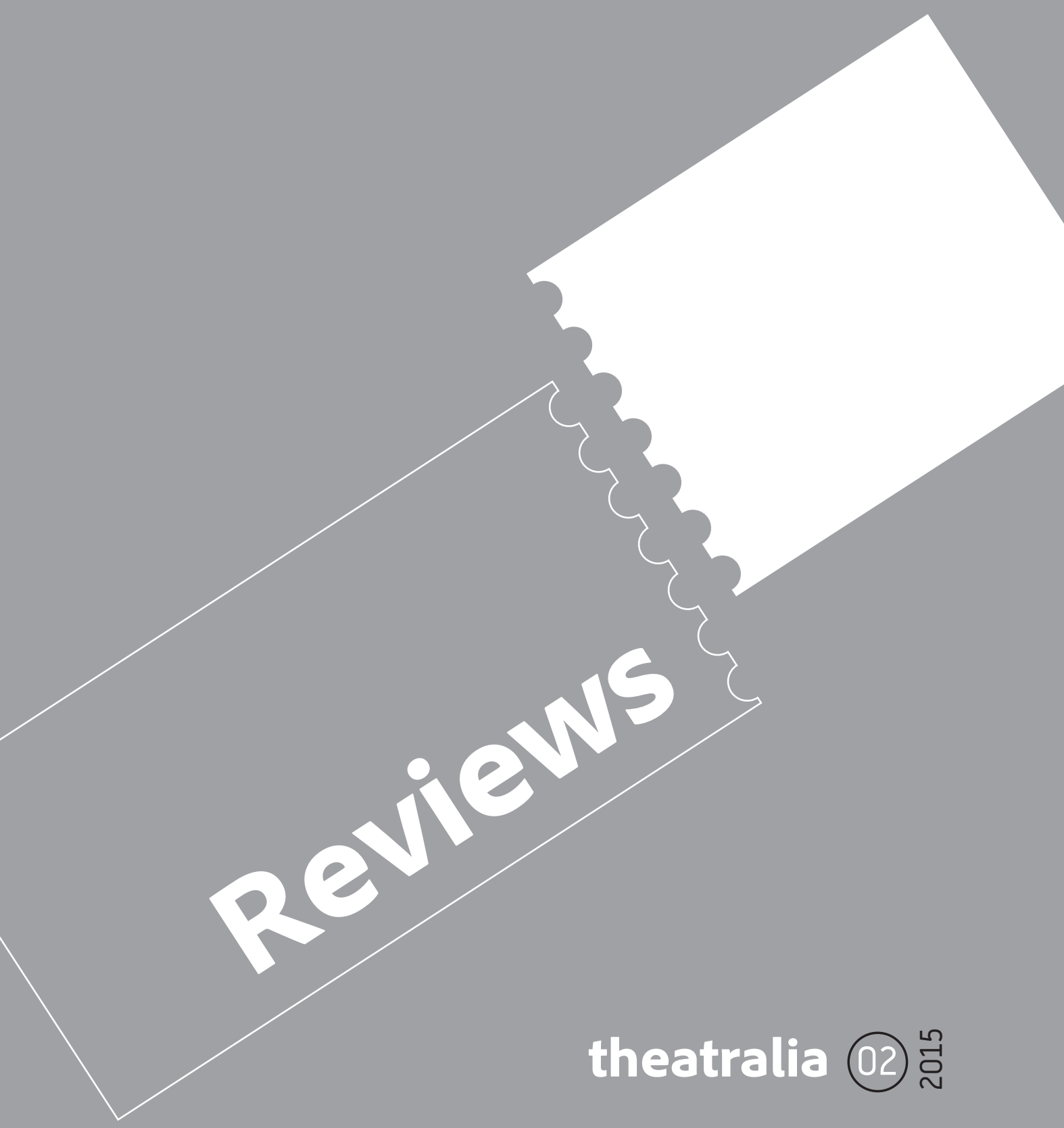





\section{Review of Petr Matásek - the Scenographic Puppet Master}

Miloslav KLÍMA et alii. Petr Matásek - prostor, hmota, divadlo. Edited by Kateřina MOCOVÁ ŠPLÍCHALOVÁ and Vladimír NOVÁK. Praha: AMU, 2013. 182pp. ISBN 978-80-7331-272-5.

In memoriam Josef Krofta (1943-2015)

Miloslav Klíma et al's illustrative book, entitled Petr Matásek. - Space, Matter, Theatre (Petr Matásek - prostor, hmota, divadlo), is introduced by the lead author as a volume 'paying a debt' to Czech scenography studies and filling in a crying gap in the discipline by means of a monograph on a leading Czech and international scenographer Petr Matásek $\left({ }^{\star} 1944\right)$. Klíma’s preface is unnecessarily apologetic: the book is more than a gap-filler; it is a wonderfully illustrated resource for the study of action scenography of which Matásek, with his one hundred and three pieces of scenography (by 2013), is a key representative and cocreator.

I take the opportunity of writing briefly about this beautiful publication - less of a book review and more of an announcement - also to write a tribute to Petr Matásek's long-term collaborator Josef Krofta, who passed away recently (on 18 March 2015), and was a key figure not only in Matásek's professional career in their paradigm-shifting collaboration in DRAK Theatre over the last quarter of the century, but also a leading personality of modern Czech puppet theatre. If Matásek is referred to here as the scenographic puppet master, the literal puppet master, who is also a shadow presence in most of the book, is Krofta - in memoriam.
The ambition of the publication is not to be a monograph but rather a source book of key documents and glosses. The first part of the book (pp. 7-43) is dedicated to 'Studies' - individual critical and theoretical reflections on Matásek's work, spanning several decades and reflecting his artistic development and the changing assessment of it. The following part (45-61) reprints period reviews of theatre productions. The pictorial core of the volume is illustrations of individual items of scenography Czech(oslovak) (63-97), international (99-106), spoken drama (107-32), opera (133-40) - and artefacts - puppets (153-9) and posters (161-75). Inset are 'Stage directors' glosses' (141-50) with personal testimonials of Matásek's collaborators (such as a version of Joe Brandesky's account of the aPOEtheosis project at the Ohio State University; see Brandesky's text in this volume). The book is completed with the artist's narrative curriculum vitae (176-81) and a list of all his scenographic works (182-4).

The material presented here documents Matásek's concept of action scenography, which he developed especially after he came from the Alfa Theatre in Pilsen to the DRAK Theatre in Hradec Králové in 1974, where, jointly with Josef Krofta, he developed the aesthetics of objects in mo- 
tion and - very importantly - their poetics of found objects engaged in theatre action. These form the above-mentioned paradigm shift in modern Czech puppet theatre, complementing the puppet as an anthropomorphic figure with its 'relatives' from the world of objects and raw matter. The free movement on the spectrum of object - animal - anthropomorphism - collage and the fluent transitions of human features into objects (such as skin and tissue into a bark-like structure) are distinctive elements of Petr Matásek's visual style.

To conclude, let me cite (in translation) the 'gloss' that the late Josef Krofta wrote of his collaborator. It is indicative of the lucky creative synergies that met at DRAK Theatre, and developed the tradition of Czech puppet theatre into yet another, unprecedented quality:

\section{Petr Matásek - schoolmate}

When we studied with Petr Matásek in the puppetry department at DAMU in the 1960 s, it was animation that was mainly taught. A whole semester or even a year we played with one type of puppets. I don't know how Petr had it with Professor Lander, but the puppet acting programme taught walking, sitting down, kneeling down, lying down with the puppet, and who managed most credibly, was the best. In other words, students learned to imitate the live actor, who was the model.

\section{Petr Matásek - puppeteer}

We discovered the puppet's power and magic first-hand only later, at DRAK, where we arrived - I from the Malé divadlo in České Budějovice and Petr from the Alfa in Pilsen. At DRAK, there were people to learn from. We both understood that the power of the puppet is first of all in that it can walk, sit down and kneel down in ways that the live actor can never dream to. Animation is far from just a movement technique but derives from the word anima, that is, the ability to breathe in the soul. The art lies in uncovering opportunities for the puppet in which it is irreplaceable. For the artist the awareness that the puppet is an equal partner as long as my actorly imagination is sufficient to inspire through its faith the un-live material with life.

[...]

\section{Petr Matásek - visual artist}

The integration of visual arts with acting in creating the shape of the production presupposes a mutual respect of both artists: the scenographer and the actor. Often respect is not enough. It has to be admiration and reverence for one another. Perhaps only in this way can one reach the patience that this awful and simultaneously beautiful addiction requires. In normal theatre, Juliet meets the scenographer usually through her stage costume. That can form her character, it can be smart, or simply just stifling. She nips off to the wardrobe - and that's it. A puppet Juliet was created by the scenographer, and if she wishes to complain in the wardrobe of her tight bodice or another imperfection, she also needs an actor. An expressive acting combined with a feel for Matásek's visual detail. That is the mystery of Petr Matásek.

$[\ldots]$ 


\section{Petr Matásek - cook}

We have spent a long time together. On tour and at home. Abroad, he usually cooked and I took on the lesser culinary chores. Peeling potatoes, cooking pasta or rice and washing up to conclude. They never let me near meat. Petr used to have such a sharp forestry knife, a few old film cases with spices and most importantly he knew how to 'simmer' meat. I don't know if he still cooks; I only wash up. As a visual artist he was, and is, always very good (144-5).

For more information on Petr Matásek, see his personal website at http://www.petrmatasek.cz

DOI: 10.5817/TY2015-2-14 